\title{
REVIEW
}

\section{Distribution in the North Pacific Ocean, Bering Sea, and Arctic Ocean of animal populations known to carry pathogenic caliciviruses}

\author{
A. W. Smith, D. E. Skilling, J. E. Barlough* \& E. S. Berry \\ Calicivirus Research Laboratory, College of Veterinary Medicine, Oregon State University, Corvallis, \\ Oregon $97331-4802$, USA
}

\begin{abstract}
Caliciviruses, once thought to infect only swine, were considered eradicated from domestic herds in 1959. Later it was discovered that related caliciviruses could be found in profuse variety amongst the creatures of the sea. Remarkably, the host spectrum of caliciviruses, which once seemed so restricted, was found to be unusually diverse and capable of bridging wide phylogenetic distances. This vital characteristic appears now to be aiding these unusual and highly adaptive viruses in crossing not only species lines but also the land-sea interface, and they apparently are again becoming established as important disease agents of land animals. The geographical distribution, host spectra, pathogenic potential, and possible public health significance of these viruses, are the subject of this review.
\end{abstract}

\section{INTRODUCTION}

Between 1932 and 1956, when vesicular exanthema of swine (VES) spread unchecked through swine herds of the United States, the causative agent, a calicivirus, became well established as an important pathogen of domestic animals (Smith 1983, Barlough et al. 1986a). For 40 yr the origin and mechanisms of spread of this agent remained obscure. It had been suggested by Shope (1955) that the virus may have originated from some wild animal source, and when this could not be confirmed others suggested a possible de novo appearance (Madin 1975, Bankowski 1965).

Beginning in 1972, a sequential series of calicivirus serotypes, all physiochemically and morphologically indistinguishable from the long-forgotten and presumably eradicated VES virus (VESV), was isolated from pinniped sources (Smith et al. 1973, 1977, 1979, 1981a). In addition, 2 serotypes were isolated from fish /Girella

\footnotetext{
- Present address: Department of Veterinary Microbiology, New York State College of Veterinary Medicine, Cornell University, Ithaca, New York 14850, USA
}

nigricans) inhabiting tidal pools along the southern California coast (Smith et al. 1980a). These fish, commonly called opaleye, are closely associated with the California sea lion, for which they serve as intermediate host for the sea lion lungworm Parafilaroides decorus. One virus isolate from the opaleye was shown to spread through exposed pigs and to cause typical VES (Smith et al. 1980a). More recently a new calicivirus has been recovered from dairy cattle in Tillamook County, Oregon, USA (Smith et al. 1983a). This agent is also indistinguishable from VESV and produces clinical VES in exposed swine. Present research shows that this virus, like VESV, is probably of marine origin (Barlough et al. 1987a).

It thus seems apparent that these marine caliciviruses are continuing to emerge from reservoirs in the ocean and are being introduced into terrestrial populations. The intent of this review is to describe the ocean distribution of the principal marine species involved in calicivirus transmission, to explore the mechanisms whereby these viruses move from the sea to land, and to discuss their role as emerging disease agents. 


\section{OCEAN DISTRIBUTION OF KNOWN RESERVOIR ANIMALS (TABLE 1)}

The California sea lion Zalophus californianus californianus (Fig. 1) appears to be involved more intimately in the calicivirus transmission cycle than any other mammalian species thus far examined. Eight separate calicivirus serotypes have now been isolated from this species (Barlough et al. 1986a, Berry et al. 1986), and nearly every individual tested has had specific antibodies to one, or more often, to many different serotypes of marine caliciviruses, including those originally isolated from swine (Smith et al. 1976, Smith \& Latham 1978). These findings indicate that a major enzootic focus of calicivirus activity exists within the California sea lion's range, which extends from Vancouver, British Columbia, as far south as the Pacific Mexican coast. Breeding occurs in the area between Baja California and San Miguel Island off the coast of Santa Barbara. In this species caliciviruses have been found in association with abortion and with vesicle formation on the flippers and possibly the mouth (for review see Barlough et al. 1986a). Calicivirus infections of sea lions have not been described north of San Francisco, but one should expect caliciviruses to be shed by carrier individuals throughout the range.

Steller (or northern) sea lions Eumetopias jubatus (Fig. 1) have a much larger range, extending from the southern limit of San Miguel Island, California north into the Bering Sea. Serologic conversions confirm that Steller sea lions have contact with marine caliciviruses (Akers et al. 1974, Barlough et al. 1986b); and very recently a single serotype of SMSV was isolated from a Steller sea lion (Skilling et al. unpubl.).

Northern fur seals Callorhinus ursinus (Fig. 1) have been closely studied for evidence of calicivirus exposure, and from this work there emerges an interesting picture. Although they are not as heavily involved with caliciviruses as Zalophus californianus, northern fur seals appear capable of transporting viruses from southern California waters to their northern breeding rookeries in the Bering Sea, where the primary mechanism of spread appears to be horizontal (Smith et al. 1976, 1980b). Vesicular lesions are known to accompany calicivirus epizootics among fur seals on the Bering Sea rookeries, and some reproductive failures in this species are suspected to be calicivirusinduced (see Barlough et al. 1986a). On San Miguel Island there are great differences between the

Table 1. Calicivirus isolation and type-specific neutralizing antibodies in ocean species

\begin{tabular}{|c|c|c|}
\hline Species & Type virus isolated & Serum antibodies \\
\hline California sea lion & $\begin{array}{l}\text { SMSV } 1-7,9,12,13 \\
\text { Cetacean calicivirus }\end{array}$ & $\begin{array}{l}\text { VESV A, C-G, I-K } \\
\text { SMSV 1-13 } \\
\text { Tillamook calicivirus } \\
\text { Cetacean calicivirus }\end{array}$ \\
\hline Steller sea lion & SMSV $6{ }^{*}$ & $\begin{array}{l}\text { SMSV } 2,5,6,13 \\
\text { Tillamook calicivirus }\end{array}$ \\
\hline Northern fur seal & SMSV $1,5,8,10,11$ & SMSV 2, 5 \\
\hline Northern elephant seal & SMSV 7 & SMSV 2 \\
\hline Hawaiian monk seal & & $\begin{array}{l}\text { SMSV } 1 \\
\text { VESV I }\end{array}$ \\
\hline Walrus & Walrus calicivirus & Walrus calicivirus \\
\hline Bowhead whale & & $\begin{array}{l}\text { VESV } J \text { and } K \\
\text { SMSV } 5\end{array}$ \\
\hline Sperm whale & & $\begin{array}{l}\text { VESV A and I } \\
\text { SMSV } 5\end{array}$ \\
\hline California gray whale & & $\begin{array}{l}\text { VESV A, D-G, I and J } \\
\text { SMSV } 2 \text { and } 5\end{array}$ \\
\hline Fin whale & & $\begin{array}{l}\text { VESV A and I } \\
\text { SMSV } 5\end{array}$ \\
\hline Opaleye fish & SMSV 6 and 7 & \\
\hline
\end{tabular}




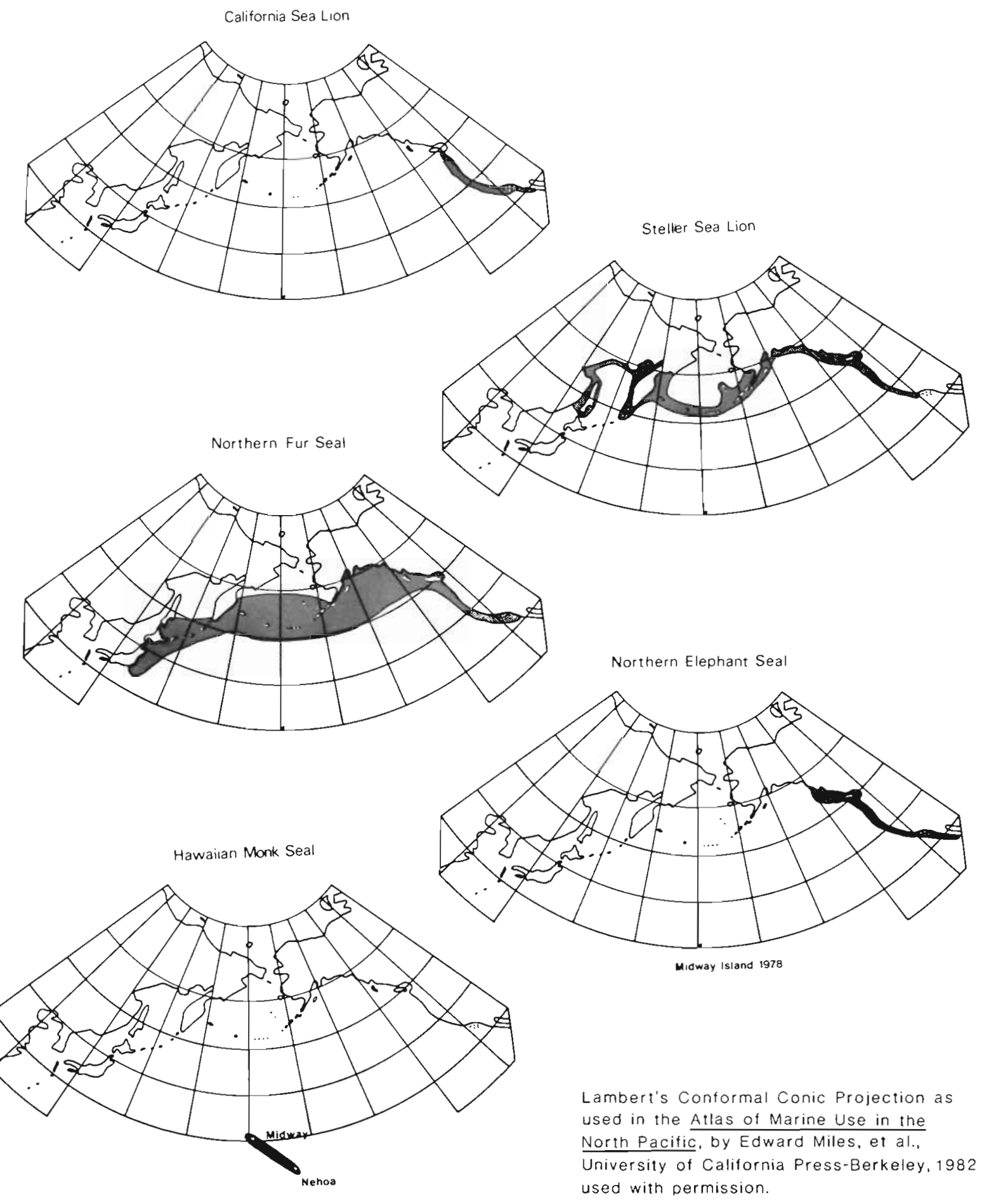

Fig. 1. Ocean distribution of known reservoir animals

calicivirus antibody profiles of California sea lions and northern fur seals of the same age (Smith et al. 1976 , Berry et al. 1986). Although both species can be found in close proximity on the rookeries, California sea lions have a much higher incidence of calicivirus infection than do co-resident fur seals. This discrepancy is thought to be the result of dissimilar feeding habits: sea lions feed on near-shore species, such as opaleye, while fur seals feed most often at the margins of the continental shelf and in deep water (Smith \& Latham 1978, King 1983).

Northern elephant seals Mirounga angustirostris 
(Fig. 1) breed between the islands off Baja California, Mexico, and the Farallon Islands outside San Francisco. Their overall range is not well defined but is probably much larger than this. For example, females and young are in general common up the Pacific coast as far north as Vancouver Island, and one yearling, tagged originally off California, has been identified on Midway Island (R. L. Delong pers. comm.). Although a calicivirus has been isolated from this species and may be associated with pup orphaning, other disease effects have not been observed (Smith et al. 1980a).

The Hawaiuan monk seal Monachus schauinslandi (Fig. 1), an endangered species, is geographically restricted to the Hawaiian Leeward Islands. These islands are undergoing geological destruction, and species tied to such habitats thus face extinction. A few monk seals were sampled in 1978, and although no caliciviruses were isolated, these seals did have typespecific antibodies to some serotypes, suggesting that caliciviruses are present also in the mid-Pacific.

Pacific walruses Odobenus rosmarus divergens (Fig. 2) have been found to carry calicivirus antibodies and also have been shown to excrete caliciviruses (Smith et al. 1983b). Antibody profiles suggest limited exposure to at least 3 different serotypes (Smith et al. 1983b, Barlough et al. 1986b). Intensive efforts are in progress to more closely examine possible disease-related effects of caliciviruses on the Pacific walrus population.

Bowhead whales Balaena mysticetus (Fig. 2) are of special interest to this discussion. Although their range is restricted to the margins of the Arctic pack ice, several serum samples from these whales have been found to contain neutralizing antibodies to 3 calicivirus serotypes previously isolated from northern fur seals in the Bering Sea (Smith 1983). Moreover, bowheads also had antibodies to 2 serotypes that had been isolated only once - from garbage-fed swine during an outbreak of VES in 1956 in Secaucus, New Jersey.

Sperm whales Physeter catodon (Fig. 2) are found in nearly all the major oceans of the world except the colder and more polar regions. A limited number of these whales have been tested, and a few have been found to carry antibodies to caliciviruses (Smith \& Latham 1978).

Gray whales Eschrichtius robustus (Fig. 2) migrate yearly from Baja California and the Gulf of California (where they calve during the winter in shallow lagoons) to their summer range up the Pacific coast into the Bering Sea, and in some instances through the Bering Strait. A number of these whales have been examined, and a high percentage show evidence of calicivirus contact. Presumably, this occurs as a result of their migration through areas of enzootic calicivirus activity, e. g. southern California (Smith et al. 1976, Smith \& Latham 1978).

Opaleye fish Girella nigricans provide an ideal maintenance or reservoir host for caliciviruses. The virus replicates in infected fish at ocean temperatures $\left(15^{\circ} \mathrm{C}\right)$ yet does not appear to produce severe disease (Smith et al. 1981b). The calicivirus first isolated from opaleye was also isolated from pinnipeds (northern elephant seals), and has been shown to produce vesicular lesions in pigs (Smith et al. 1980a). Opaleye are found as juveniles in tidal pools along the California coast south from Point Conception and, as previously mentioned, serve as intermediate hosts for the sea lion lungworm. Assuming this fish is a primary or a major reservoir for the marine caliciviruses, then its close ecological proximity to the Californid sed lion would provide an attractive explanation for the exceptionally high frequency of calicivirus antibodies in Zalophus californianus.

\section{MOVEMENT ASHORE OF CALICIVIRUS}

There are several very obvious ways by which ocean materials may be borne inland. Perhaps the easiest to visualize (and the most important in historic terms) would be the catch of ocean fish brought ashore and eaten by people and animals. If these fish are not processed in ways that inactivate viruses (e. g. thorough cooking), then they could provide an excellent source of infectious virus. Another mechanism, although not yet proven, involves the runs of anadromous fish, such as salmon, that migrate up Pacific coastal fresh waterways.

Tidal flush and surf are obvious microbiological carriers, but a more subtle exchange mechanism is the action of bubbles rising through the water and bursting at the surface. This mechanism is a particularly attractive possibility considering that a $1.5 \mathrm{~mm}$ bubble rising a few cm through water is a rather efficient scavenger of organic particulates, such as viruses (Blanchard 1975). The bursting of bubbles at the surface may project virus-laden droplets $15 \mathrm{~cm}$ into the air, where they can be borne on air currents or prevailing winds for considerable distances (Blanchard 1975).

For our discussion, the most obvious mechanism for the movement of aquatic agents into land would involve animals that readily bridge the intertidal zone: the pinnipeds. These animals traverse great ocean distances over which they can be exposed potentially to many different kinds of microbial agents. They then 'haul out' on land, at various times and places, where they can exchange these agents with local terrestrial species. Another type of marine mammal movement occurs that could also be of significance: the harvest of 
Walrus

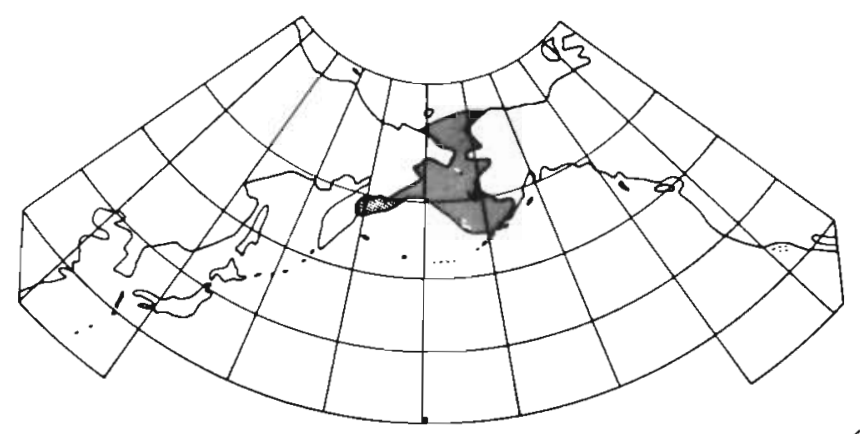

Bowhead Whale
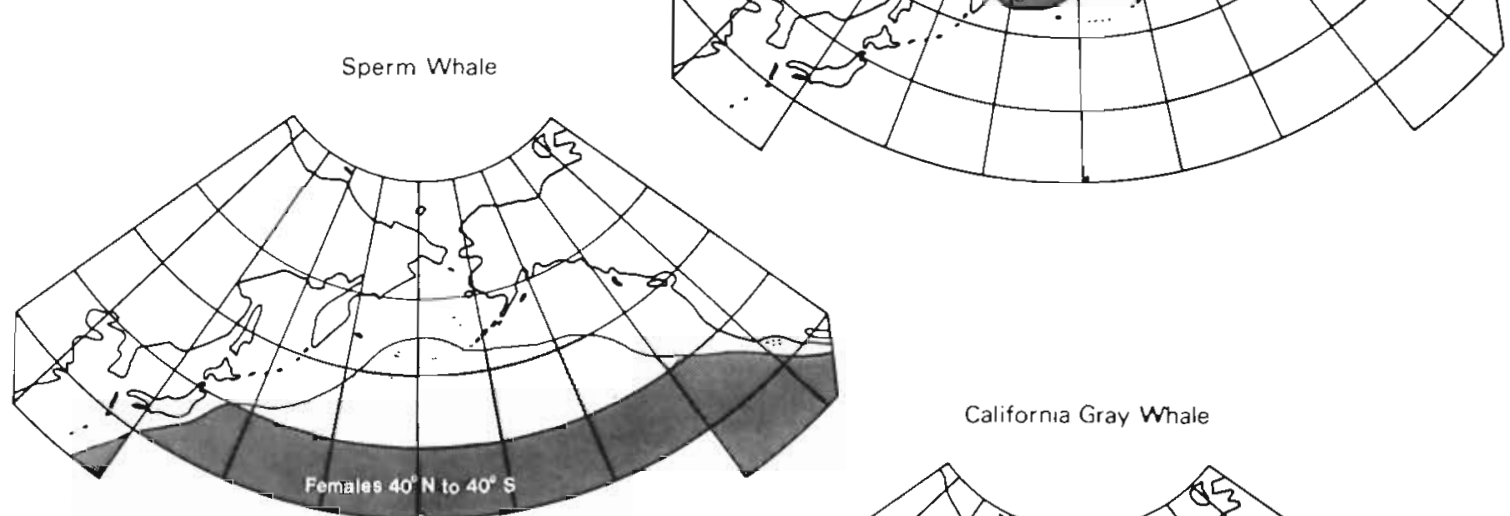

Californı Gray Whale

Opaleye

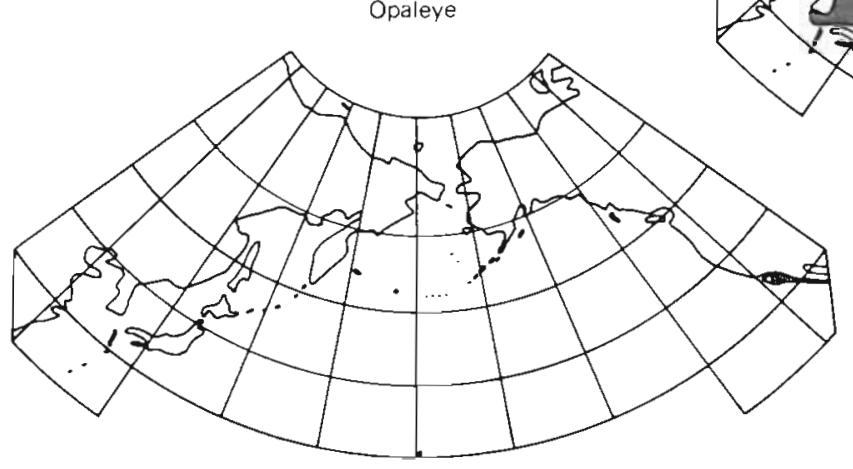

Lambert's Conformal Conic Projection as used in the Allas of Marine Use in the North Pacific, by Edward Miles, et al., University of California Press-Berkeley, 1982 used with permission.

Fig. 2. Ocean distribution of known reservoir animals

marine mammal species, and the subsequent transport of their component parts to inland destinations. It is believed that this mechanism may have been responsible for exposure of swine in Idaho and Utah to caliciviruses, after these pigs had eaten or otherwise contacted meat from northern fur seal carcasses (Sawyer et al. 1978, Soergel et al. 1978).

\section{LAND ANIMALS INFECTED WITH MARINE CALICIVIRUSES (TABLE 2)}

Even though caliciviruses of marine origin have actually been isolated from 2 terrestrial species, the hog and cow, there is serologic evidence suggesting that a number of other species also have been infected. 
These are all insular species sampled on the Santa Barbara Channel Island chain, and include the indigenous gray fox and feral population of buffalo, and the once domesticated sheep, donkey and swine (Smith \& Latham 1978). One can imagine that foxes might contact the virus by scavenging; however, this particular insular species does not appear to obtain much, if any, of its food from the island beaches. Feral swine, on the other hand, are recognized beach scavengers and might be exposed by eating infected seal carcasses or fishes. The herbivorous species buffalo, sheep, and donkey - would be exposed more probably by virus-laden aerosols contaminating forages.

One particular point of great interest is the finding of a new calicivirus, tirst isolated from cattle (Tillamook calicivirus or, more properly, bovine calicivirus Bos-1 [BCV Bos-1]) (Smith et al. 1983a), which also appears to have infected marine mammals along our Pacific shores from southern California to Alaska (Barlough et al. $1987 \mathrm{a}$ ). Also of interest is the recent detection of serum-neutralizing antibodies specific for SMSV-13 (a new calicivirus serotype isolated from California sea lions in 1984) among domestic cattle in Oregon (Berry et al. 1986). The mechanism whereby land animals (dairy and beef cattle in Oregon) became infected with these agents is unclear, but commercial feed supplements containing Pacific marine fisheries products would be suspect.

\section{LAND ANIMALS WITH CALICIVIRUS INFECTION OF UNKNOWN BUT POSSIBLE MARINE ORIGIN}

There are in addition calicivirus isolates from terrestrial animals for which evidence of a marine origin is lacking:

Five species of primates housed at the San Diego Zoo have been found to shed one particular calicivirus serotype (Smith et al 1983c, 1985a, b). The origin of this agent is unknown, but San Diego is a southern California city with a close coastal proximity. Also, at the San Diego Zoo, another calicivirus serotype has been recovered from 3 species of venomous snakes and from 2 Bell's horned frogs, representing the first isolation of a calicivirus from terrestrial poikilotherms (Smith et al. 1986).

A mink calicivirus has been isolated, and serologic studies indicate that it is widely distributed in domestic mink populations (Long et al. 1980). The origin of this agent is also unknown, but one should note the importance of fisheries products as a protein source for mink, and the documented utilization of ground fur seal carcasses ('sealburger') as a red meat source for western ranch mink (Sawyer et al, 1978, Long et al. 1980, Evermann et al. 1983).

Recently, several caliciviruses have been isolated from dogs. Although most of these appear to be feline caliciviruses, some are not. One member of this latter group was isolated from vaginal vesicles while another was isolated from a dog with diarrhea (R. A. Crandell pers. comm., Schaffer et al. 1985). The feline caliciviruses themselves are found worldwide wherever there are domestic cats. However, the feline calicivirus story is unusual in that virtually all feline caliciviruses represent variants of a single serotype, and they are almost exclusively feline host-specific (Kalunda et al. 1975). An exception is the recent and apparently rare occurrence of feline caliciviruses in dogs (Evermann et al. 1983). One should be reminded that dogs as a species are frequently in direct contact with cats. One might also recall the fondness of cats for fish products, when pondering the possible origin of the feline caliciviruses.

A final series of caliciviruses or calicivirus-like agents should be mentioned. These all are linked by 2 common factors: most of them have yet to be propagated in vitro, and all are associated with gastroenteritis. These agents have been demonstrated by electron microscopy in feces of piglets (Saif et al. 1980), chickens (Wyeth et al. 1981), and humans (Cukor \& Blacklow 1984). Some outbreaks in humans have been traced to shellfish and other foods of marine origin, although this may be merely coincidental because these agents are recognized to be spread primarily through contaminated food and water (Cukor \& Blacklow 1984).

\section{DISEASE POTENTIAL OF CALICIVIRUSES}

Most caliciviruses that have been closely studied to date cause disease. Most frequently described have been vesicles and erosions found on the feet, flippers, and mouth (Bankowski 1965, Madin 1975, Smith 1983, Barlough et al. 1986a). In addition, these agents have been associated with reproductive failure, primarily abortion and agalactia. They cause pneumonitis, myocarditis and encephalitis in species that have been studied experimentally. They are important pathogens that can cause severe disease.

\section{TRANSMISSION TO HUMANS}

Although clinical disease in human beings has not been associated with exposure to the marine caliciviruses, there are 5 compelling reasons for suggesting that these agents may indeed affect humans: 
Table 2. Calicivirus isolation and type-specific neutralizing antibodies in terrestrial animals

\begin{tabular}{|c|c|c|}
\hline Species & Type of virus isolated & Serum antibodies ${ }^{\circ}$ \\
\hline Feral swine & & $\begin{array}{l}\text { VESV A, C-E, G, I-K } \\
\text { SMSV } 1,2 \text { and } 5\end{array}$ \\
\hline Domestic swine & $\begin{array}{l}\text { SMSV } 4 \\
\text { VESV A-J }\end{array}$ & SMSV 4,5 \\
\hline Foxes & & SMSV 2-5 \\
\hline Feral donkey & & $\begin{array}{l}\text { VESV I } \\
\text { SMSV } 2\end{array}$ \\
\hline Domestic cattle & Tillamook calicivirus & $\begin{array}{l}\text { Tillamook calicivirus } \\
\text { SMSV } 5 \text { and } 13\end{array}$ \\
\hline Primates (zoologic) & Primate calicivirus. & Primate calicivirus \\
\hline Reptiles (zoologic) & Reptile calicivirus ${ }^{*}$ & \\
\hline Amphibian (zoologic) & Reptile calicivirus $\cdot$ & \\
\hline Mink (farm) & Mink calicivirus ". & Mink calicivirus \\
\hline
\end{tabular}

(1) Virtually all of the known calicivirus serotypes were isolated originally in primate cell lines (Vero), or can be propagated routinely in these lines. In addition, most will grow readily in a number of human cell lines.

(2) Several researchers who have worked extensively with these agents in the laboratory and in the field have developed neutralizing antibodies against them, strongly suggesting unrecognized infection (Smith et al. 1978, Soergel et al. 1978).

(3) Three of these marine caliciviruses have been experimentally inoculated into nonhuman primates, and all 3 have produced lesions at the sites of inoculation, with subsequent virus shedding (Smith et al. 1978).

(4) Two species of great apes - the pygmy chimpanzee Pan paniscus and the lowland gorilla Gorilla gorilla - as well as 3 other species of nonhuman primates have been shown to harbor calicivirus infections (Smith et al. 1983c, 1985a, b).

(5) Many caliciviruses can infect several animal species, and one serotype that has been quite carefully studied is known to infect fishes, seals, mink, pigs and primates. This phylogenetic diversity of host species, ranging from fishes to primates, supports extrapolation of the calicivirus host range to include human beings.

In summary, the known host species and their ocean distribution of a viral pathogen has been described. The caliciviruses are uniquely marine in origin, and are being transported in a number of ways from ocean reservoirs to new host species on the land. They are now being recognized in and recovered from an increasing array of divergent species. These viruses of marine origin are developing a remarkable plasticity and are rapidly becoming recognized worldwide as disease agents of considerable importance.

Acknowledgements. This work was supported by the Oregon Agricultural Experiment Station, Oregon State University, Corvallis, Oregon 97331-4802, USA, Oregon Agricultural Experiment Station Technical Paper No. 7600 .

\section{LITERATURE CITED}

Akers, T. G., Smith, A. W., Latham, A. B., Watkins, H. M. S. (1974). Calicivirus antibodies in California grey whales (Eschrichtius robustus) and Steller sea lions (Eumetopias jubatus). Arch. ges. Virusforsch. 46: 175-177

Bankowski, R. A. (1965). Vesicular exanthema. Adv. vet. Sci. 10: 23-64

Barlough, J. E., Berry, E. S., Skilling, D. E., Smith, A. W. (1986a). Sea lions, caliciviruses, and the sea. Avian/Exotic Practice 3: 8-20

Barlough, J. E., Berry, E. S., Skilling, D. E., Smith, A. W., Fay, F. H. (1986b). Marine calicivirus antibodies in the Pacific walrus. J. Wildl. Dis, 22: 165-168

Barlough, J. E., Berry, E. S., Smith, A. W., Skilling, D. E. (1987a). Prevalence and distribution of serum-neutralizing antibodies to Tillamook (bovine) calicivirus in selected marine mammal populations. T. Wildl. Dis. (in press)

Barlough, J. E., Berry, E. S., Goodwin, E. A., Brown, R. F., Delong, R. L., Smith, A. W. (1987b). Antibodies to marine caliciviruses in the Steller sea lion (Eumetopias jubatus Schreber). J. Wildl. Dis. (in press)

Berry, E. S., Barlough, J. E., Skilling, D. E., Smith, A. W., Vedros, N. A. (1986). Calicivirus isolation from an outbreak of vesicular disease in California pinnipeds. In: Otter, T. (ed.) Proceeding of the 16th Annual Conference and Workshop of the International Association of Aquatic Animal Medicine, Tacoma, Washington, p. 102-107

Blanchard, D. C. (1975). Bubble scavenging and the water-to- 
air transfer of organic material in the sea. Adv. Chem. 145: $360-387$

Cukor, G., Blacklow, N. R. (1984). Human viral gastroenteritis. Microb. Rev. 48: 157-179

Evermann, J. F., Smith, A. W., Skilling, D. E., McKeirnan, A. J. (1983). Ultrastructure of newly recognized caliciviruses of the dog and mink. Arch. Virol. 76: 257-261

Kalunda, M., Lee, K. M., Holmes, D. R., Gillespie, J. H. (1975). Serologic classification of feline caliciviruses by plaquereduction neutralization and immunodiffusion. Am. J. vet. Res. 36: 353-356

King, J. E. (1983). Seals of the world, 2nd edn. Cornell University Press, Ithaca, p. 23-27 and 61-65

Long, G. G., Evermann, J. F., Gorham, J. R. (1980). Naturally occurring picornavirus infection of domestic mink. Can. J. compar. Med. 44: 412-417

Madin, S. H. (1975). Vesicular exanthema. In: Dunne, H. W., Leman, A. D. (ed.) Diseases of swine, 4 th edn. Iowa State University Press, Ames, p. 285-307

Saif, L. T., Bohl, E. H., Theil, K. W., Cross, R. F., House, T. A. (1980). Rotavirus-like, calicivirus-like, and 23-nm viruslike particles associated with diarrhea in young pigs. $T$. Clin. Micro. 12: 105-111

Sawyer, J. C., Madin, S. H., Skilling, D. E. (1978). Isolation of San Miguel sea lion virus from samples of an animal food product produced from northern fur seal (Callorhinus ursinus/ carcasses. Am. J. vet. Res. 39: 137-139

Schaffer, F. L., Soergel, M. E., Black, J. W., Skilling, D. E., Smith, A. W., Cubitt, W. D. (1985). Characterization of a new calicivirous isolated from feces of a dog. Arch. Virol. 84: 181-195

Shope, R. E. (1955). Epizoology of virus diseases. Adv. vet. Sci. Vol. II. Academic Press, New York, p. 1-41

Smith, A. W. (1983). Focus on ... caliciviral disease. USDA Foreign Animal Disease Report, N. 11-3, p. 8-16

Smith, A. W., Latham, A. B. (1978). Prevalence of vesicular exanthema of swine antibodies among feral mammals associated with the southern California coastal zones. Am. J. vet. Res. 39: 291-296

Smith, A. W., Akers, T. G., Medin, S. H., Vedros, N. A. (1973). San Miguel sea lion virus isolation, preliminary characterization and relationship to vesicular exanthema of swine virus. Nature, Lond. 244: 108-110

Smith, A. W., Akers, T. G., Prato, C. M., Bray, H. (1976). Prevalence and distribution of four serotypes of SMSV serum neutralizing antibodies in wild animal populations. J. Wildl. Dis. 12: 326-334

Srnith, A. W., Prato, C. M., Skilling, D. E. (1977). Characterization of two new serotypes of San Miguel sea lion virus. Intervirology 8 : 30-36
Smith, A. W., Prato, C., Skilling, D. E. (1978). Caliciviruses infecting monkeys and possibly man. Am. J. vet. Res. 39 $287-289$

Smith, A. W., Akers, T. G., Latham, A. B., Skilling, D. E., Bray, H. L. (1979). A new calicivirus isolated from a marine mammal. Arch. Virol. 61: 255-259

Smith, A. W., Skilling, D. E., Dardiri, A. H., Latham, A. B. (1980a). Calicivirus pathogenic for swine: a new serotype isolated from opaleye Girella nigricans, an ocean fish. Science 209: 940-941

Smith, A. W., Skilling, D. E., Brown, R. J. (1980b). Preliminary investigation of a possible lungworm (Parafilaroides decorus), fish (Girella nigricans), and marine mammal (Callorhinus urirus) cycle for San Miguel sea lion virus type 5. Am. J. vet. Res. 41: 1846-1850

Smith, A. W., Skilling, D. E., Latham, A. B. (1981a). Isolation and identification of five new serotypes of calicivirus from marine mammals. Am. J, vet. Res. 42: 693-694

Smith, A. W., Skiling, D. E., Prato, C. M., Bray, H. L. (1981b). Calicivirus (SMSV-5) infection in experimentally inoculated opaleye fish (Girella nigricans). Arch. Virol. 67: 165-168.

Smith, A. W., Mattson, D. E., Skilling, D. E., Schmitz, J. A. (1983a). Isolation and partial characterization of a calicivirus from calves. Am. J. vet. Res. 44: 851-855

Smith, A. W., Ritter, D. G., Ray, C. C., Skilling, D. E., Wartzok, D. (1983b). New calicivirus isolates from feces of walrus (Odobenus rosmarus). J. Wildl. Dis. 19: 86-89

Smith, A. W., Skilling, D. E., Ensley, P. K., Benirschke, K. Lester, T. L. (1983c). Calicivirus isolation and persistence in a pygmy chimpanzee (Pan paniscus). Science 221: $79-81$

Smith, A. W., Skilling, D. E., Anderson, M. P., Benirschke, K. (1985a). Isolation of primate calicivirus Pan paniscus type 1 from a douc langur (Pygathrix nemaeus Linne). J. Wildl. Dis. $21: 426-428$

Smith, A. W., Skilling, D. E., Benirschke, K. (1985b). Calicivirus isolation from three species of primates: an incidental finding. Am. J. vet. Res. 46: 2197-2199

Smith, A. W., Anderson, M. P., Skilling, D. E., Barlough, J. E., Ensley, P. K. (1986). First isolation of calicivirus from reptiles and amphibians. J. Am. vet. med. Ass. 47: $1718-1721$

Soergel, M. E., Schaffer, F. L., Sawyer, J. C., Prato, C. M. (1978). Assay of antibodies to caliciviruses by radioimmune precipitation using staphylococcal protein $\mathrm{A}$ as IgG absorbent. Arch. Virol. 57: 271-282

Wyeth, P. T., Chettle, N. T., Labram, T. (1981). Avian caliciviruses, Vet. Rec. 109: 477 